\title{
Integrated Models of the Land System: A Review of Modelling Approaches on the Regional to Global Scale
}

\author{
Rüdiger Schaldach \\ Center for Environmental Systems Research \\ University of Kassel, Kurt-Wolters-Str. 3, \\ D-34109 Kassel, Germany \\ email: schaldach@usf.uni-kassel.de \\ http://www.usf.uni-kassel.de/cesr/ \\ Jörg A. Priess \\ Center for Environmental Systems Research \\ University of Kassel, Kurt-Wolters-Str. 3, \\ D-34109 Kassel, Germany \\ email: priess@usf.uni-kassel.de \\ http://www.usf.uni-kassel.de/cesr/
}

\section{Living Reviews in Landscape Research ISSN 1863-7329}

Accepted on 25 March 2008

Published on 5 April 2008

\begin{abstract}
Land-use change has been identified as one the most important processes to understand and to model global change. It is the result of complex interactions between human and environmental driving factors. A key to capturing this complexity is the analytical framework of land systems as coupled human-environment systems, a concept that is a central component of the science plan of the Global Land Project. Based on this framework, this paper presents an overview of eight integrated models of the land system. The review concentrates on model approaches that include processes of both the human and the environment sub-system and which operate in a spatially explicit manner on a regional to global scale. Another criterion used to select models is that they take into account interplay and competition between different land-use activities, e.g. between agriculture and urban development. Each model is reviewed separately in detail with focus on the different aspects of the land system that are represented within the model and on the implemented modelling concepts. This is done by systematically addressing the following topics: model purpose and application, model concepts for the human sub-system and for the environment sub-system and linkages between the sub-systems (model integration). Based on these findings commonalities and differences between the models are discussed and further research needs are identified.
\end{abstract}

Keywords: land system, integrated modelling, human-environment interactions

This review is licensed under a Creative Commons Attribution-Non-Commercial-NoDerivs 2.0 Germany License. http://creativecommons .org/licenses/by-nc-nd/2.0/de/ 


\section{Imprint / Terms of Use}

Living Reviews in Landscape Research is a peer reviewed open access journal published by the Leibniz Centre for Agricultural Landscape Research (ZALF), Eberswalder Straße 84, 15374 Müncheberg, Germany. ISSN 1863-7329.

This review is licensed under a Creative Commons Attribution-Non-Commercial-NoDerivs 2.0 Germany License: http://creativecommons.org/licenses/by-nc-nd/2.0/de/

Because a Living Reviews article can evolve over time, we recommend to cite the article as follows:

Rüdiger Schaldach and Jörg A. Priess,

"Integrated Models of the Land System: A Review of Modelling Approaches on the Regional to Global Scale",

Living Rev. Landscape Res., 2, (2008), 1. [Online Article]: cited [<date $>$ ], http://www.livingreviews.org/lrlr-2008-1

The date given as $<$ date $>$ then uniquely identifies the version of the article you are referring to.

\section{Article Revisions}

Living Reviews supports two different ways to keep its articles up-to-date:

Fast-track revision A fast-track revision provides the author with the opportunity to add short notices of current research results, trends and developments, or important publications to the article. A fast-track revision is refereed by the responsible subject editor. If an article has undergone a fast-track revision, a summary of changes will be listed here.

Major update A major update will include substantial changes and additions and is subject to full external refereeing. It is published with a new publication number.

For detailed documentation of an article's evolution, please refer always to the history document of the article's online version at http://www.livingreviews.org/lrlr-2008-1. 


\section{Contents}

1 Introduction $\quad 5$

2 Conceptual model of land systems $r$

3 Integrated models of the land system $\quad \mathbf{8}$

3.1 CLUE modelling framework . . . . . . . . . . . . . . . . . . . . . . . . . . . . . . . . .

3.2 GEONAMICA framework . . . . . . . . . . . . . . . . . . . . . . . . . . . . . . . . . . . . . . . . . . . . . .

3.3 IMAGE model . . . . . . . . . . . . . . . . . . . . . . . . . . . . . . . . . . . . . . . . . . . . . .

$3.4 \mathrm{ITE}^{2} \mathrm{M}$ model network . . . . . . . . . . . . . . . . . . . . . 13

3.5 LANDSHIFT model . . . . . . . . . . . . . . . . . . . . . . . . . 14

3.6 Patuxent Landscape Model (PLM) . . . . . . . . . . . . . . . . . . . . 16

3.7 SITE model . . . . . . . . . . . . . . . . . . . . . . . . . . . . . . . . . . . . . . . . . .

3.8 SYPRIA model . . . . . . . . . . . . . . . . . . . . . . . 19

4 Discussion: Modelling of the land system $\quad 21$

4.1 Representation of the human sub-system . . . . . . . . . . . . . . . . . 21

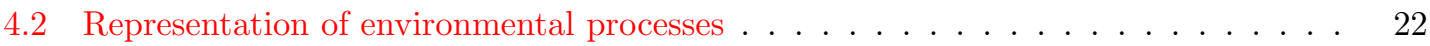

4.3 Model integration . . . . . . . . . . . . . . . . . . . . . . . . . . . . . . . . . . . . . . . .

4.4 Model application and adaptation to other geographic regions . . . . . . . . . . 24

5 Conclusion $\quad 26$

$\begin{array}{lr}\text { References } & \mathbf{2 7}\end{array}$

\section{List of Tables}

1 Overview of the models under review . . . . . . . . . . . . . . . . . . . . 8

2 Main characteristics of the reviewed models . . . . . . . . . . . . . . . . . 23 



\section{Introduction}

Land-use change is considered as one of the most important processes when attempting to understand and model global change (Foley et al., 2005). Conversion of natural land worldwide has been identified as a key driver for the release and uptake of carbon dioxide from the biosphere (e.g. Achard et al., 2004), for changing of green water fluxes (Rockström et al., 1999) and for the decrease of biological diversity (Sala et al., 2000). During the past 10 years substantial research has been conducted on land-use processes (Lambin and Geist, 2006) and on how they affect human societies, so that there is a much clearer understanding of these processes and a much better appreciation of their complexity.

As there is currently no single theory to describe all the complexities involved (Veldkamp et al., 2001), a variety of simulation models have been developed during the past years to simulate changing land-use and land-cover pattern. The problem domain of these models ranges from urbanization (e.g. Couclelis, 1997; Clarke et al., 1997) over management of coastal zones (e.g. de Kock et al., 2001) to deforestation (e.g. Pontius Jr et al., 2001). Existing reviews of land-use models develop classification schemes that are either focused on model application or on methodological issues. Examples of the first category are Lambin et al. (2000), who evaluate models in respect of their ability to simulate agricultural intensification, and Heistermann et al. (2006) who concentrate on global and continental scale applications. Both reviews categorize models according to the underlying model principles (i.e. empirical-statistical, economic and process-based). In both reviews, the term "integration" refers to the combination of different model approaches. Other reviews of this category concentrate on economic models of deforestation (Angelsen and Kaimowitz, 1999), on agricultural trade (van Tongeren et al., 2001; Balkhausen and Banse, 2004) and on model approaches for analysing of impact of multifunctional agriculture (Rossing et al., 2007). Examples of the second group of reviews (based on methodological issues) are Verburg et al. (2004) who discuss model concepts like driving forces, spatial interaction or level of integration as well as Verburg et al. (2006a) and Agarwal et al. (2002) who use model characteristics like spatial versus non spatial or dynamic versus static as discriminators. Moreover, Parker et al. (2002) concentrate on multi-agent systems.

In this paper we develop a framework for model review, taking a strict system oriented perspective, which is based on the conceptual model of land systems defined within the Science plan of the Global Land Project (GLP, 2005). The key elements of these systems serve as major categories to analyse the structure and functionality of state-of-the-art land system models for the regional to global scale. Section 2 introduces the conceptual model of land systems. In Section 3, first the review framework and the criteria that were used to select the different models are described. Then, each model is analysed in detail, according to the defined review categories. The discussion synthesizes the findings of the model review and further addresses questions of model application and adaptation to other geographic regions. Finally, further research needs are identified. 


\section{Conceptual model of land systems}

The relation between human land-use activities and environmental change can be described as a coupled human-environment system with socio-economic as well as ecological and biophysical components as sub-systems (Mather, 2006). These "land systems" form the terrestrial part of the Earth System and therefore are critical components of global biogeochemical cycles and energy fluxes (GLP, 2005). For example, agriculture is influenced by weather and climate and in turn affects climate by energy and water fluxes and the release of greenhouse gases such as carbon dioxide and nitrous oxide. Figure 1 shows the components of a "land system" and their linkages as defined within the Science Plan of the Global Land Project (GLP, 2005, p. 8, Fig. 4).

\section{Land system}

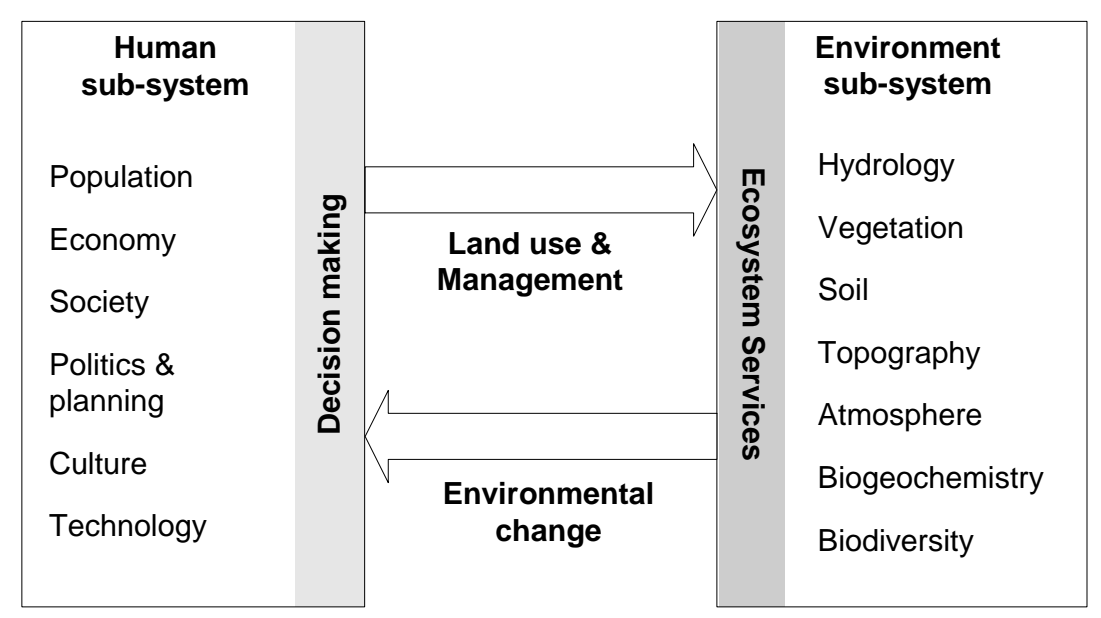

Figure 1: Conceptual model of a land system, based on GLP (2005, p. 8, Fig. 4).

In order to describe the functioning of the human sub-system, we build upon Geist and Lambin (2002) who introduce a two level hierarchy of proximate and underlying causes (or drivers) for explaining tropical deforestation. Proximate causes are human land-use activities at the local level (e.g. agricultural expansion and infrastructure extension) while underlying causes are fundamental societal processes that underpin the proximate causes and either operate on the local level or are influenced by processes on the national or global level. They include demographic, macro-economic, technological, policy and cultural factors.

According to this approach, the level of proximate drivers of the human sub-system covers processes of human decision making that directly lead to land-use changes at a certain location. In contrast, the level of underlying drivers of the human sub-system is used to describe dynamics at a larger scale level (region, country, globe) that have an effect on the local decision making process. For example, prices for agricultural commodities can be described as the result of international economic markets and policies on the underlying level but have a direct affect on management decisions of farmers on the local level.

The environment sub-system is characterized by the complex interplay between a-biotic and biotic factors and processes within natural and managed ecosystems (e.g. hydrology, soil, vegetation, biodiversity) that provide goods and services to the human sub-system, such as crop yields, clean air and potable water (GLP, 2005).

The human and the environment sub-systems are closely linked. Human land-use and management activities can lead to changes in the functioning of ecosystem processes and consequently to

Living Reviews in Landscape Research

http://www. livingreviews.org/lrlr-2008-1 
its ability to provide the aforementioned goods and services. This environmental change in turn can affect the human sub-system both on the underlying and proximate level. An example for such feedback mechanisms is non-sustainable agricultural management that leads to soil degradation, for example in form of erosion or soil nutrient depletion. The resulting soil degradation causes a decrease of the ecosystem service "crop yield" (environmental change) which in turn forces the farmer either to adapt his agricultural management practice or sooner or later to abandon his land. These links between system components, or in other words feedback mechanisms and their representation in integrated models, are one of the foci of this paper. 


\section{Integrated models of the land system}

In this paper, we review recent integrated models that simulate the functioning of the land system. The selection of models is based on criteria that we regard as characteristic for this type of model. (1) The first criterion is the argument that the simulation of the dynamics of the coupled humanenvironment system requires the inclusion of processes of both the human and environment subsystem into the model. (2) In order to stress the integrated approach, only models which focus on the interplay and competition between different land-use activities (e.g. between agriculture and urban development) and their environmental consequences are taken into account. (3) As third criterion, we concentrate on geographically explicit models that are designed for regional and watershed scale level $\left(>1000 \mathrm{~km}^{2}\right)$ up to the global scale level. Based on a review of the literature, we identified eight models that meet our criteria (Table 1).

Table 1: Overview of the models under review. (Note that throughout this paper we applied an alphabetical listing of models, whenever more than one model is mentioned.)

\begin{tabular}{|l|l|l|l|}
\hline Model & Scale level & Case study regions & First description \\
\hline CLUE & $\begin{array}{l}\text { Regional - Conti- } \\
\text { nental }\end{array}$ & Several case studies & Veldkamp and Fresco (1996) \\
\hline GEONAMICA & Regional & Several case studies & MODULUS (2000) \\
\hline IMAGE & Global & Global assessments & $\begin{array}{l}\text { Alcamo et al. (1998) } \\
\text { MNP (2006) }\end{array}$ \\
\hline ITE ${ }^{2}$ M & Regional & Lahn-Dill region, Germany & Frede et al. (2002) \\
\hline LANDSHIFT & Country - Global & Africa and India & $\begin{array}{l}\text { Alcamo and Schaldach (2006) } \\
\text { Schaldach et al. }(2006)\end{array}$ \\
\hline PLM & Regional & Patuxent watershed, USA & Costanza et al. (2002) \\
\hline SITE & Regional & Sulawesi, Indonesia & Priess et al. (2007a,b) \\
\hline SYPRIA & Regional & Southern Yucatán, Mexico & Manson (2006) \\
\hline
\end{tabular}

The review framework is based on the conceptual model for "land systems" described in the last section. On an abstract level these systems are composed of three basic elements: the human sub-system, the environment sub-system and the links and feedbacks between them. In our framework, we use these elements as categories for identifying the different aspects of land systems that are considered by the selected models and for analyzing the implemented modelling concepts. Additionally, a category describing model purpose and application is introduced.

\section{Model purpose and application}

This category covers the scientific question that the model is built for and general aspects of the underlying model philosophy and the spatial scale levels, the model is used on. Moreover, we give examples of studies conducted with the model in order to illustrate its field of application.

\section{Model concepts for the human sub-system}

Here, we discuss the modelling concepts representing the different aspects of the human subsystem. We identify, which parts of the human sub-system are endogenously modelled and which are assumed as exogenous variables. For the endogenous parts, we review the modelling approaches

Living Reviews in Landscape Research

http://www. livingreviews . org/lrlr-2008-1 
both for the level of underlying causes (e.g. economic development and demography) and for landuse decision making as well as the spatial scale level these approaches are designed for.

\section{Model concepts for the environment sub-system}

Under this headline we examine, which parts of the environment sub-system are included in the integrated model, their scale level and implemented modelling approaches.

\section{Model integration}

Model integration describes the linkages and feedbacks between the models for the human and environmental sub-systems. We examine how the coupled model represents the influence of human activities on environmental factors and in turn, how changing environmental properties affect human land-use decisions and other aspects of the human sub-system.

\subsection{CLUE modelling framework}

\section{Model purpose and application}

The CLUE (Conversion of Land Use and its Effects) modelling framework is described as a tool for quantitative multi-scale analysis of actual land use and the modelling of land-use change scenarios (Verburg et al., 1999a). Based on this framework, a family of different models has been developed. The original application of CLUE focuses on the national and continental scale with grid cell sizes between $7 \times 7 \mathrm{~km}$ and $32 \times 32 \mathrm{~km}$. To each cell a relative cover of land-use types is assigned. Examples of model applications are studies concerned with land-use change in China (Verburg et al., 1999c), the influence of high population pressure on land-use change on Java, Indonesia (Verburg et al., 1999b) and deforestation caused by the expansion of grazing activities in the Neotropics (Wassenaar et al., 2007). In contrast, the CLUE-S model version (Verburg et al., 2002) uses a finer grid resolution of $1 \times 1 \mathrm{~km}$. Here, each grid cell has a dominant land-use type. Originally designed for the regional or watershed level, it has recently been applied on the continental scale for a European-wide scenario analysis, together with the IMAGE model (Verburg et al., 2006b). While the CLUE framework focuses on the human aspects of the land system, in several studies the derived models have been coupled to environmental models for the estimation of greenhouse gas emissions (Verburg and Denier van der Goon, 2001), soil erosion (Verburg, 2006) and carbon and nutrient fluxes (Priess et al., 2001).

\section{Model concepts for the human sub-system}

The model concepts for the representation of the human sub-system differ between the various models derived from the CLUE framework. The original CLUE model combines empirical-statistical elements with dynamic simulation to model the spatial dynamics of land-use change. The empiricalstatistical model part comprises methods to analyse and model statistical relations between the observed land-use pattern and socio-economic (e.g. income, population density), geographical (e.g. distance to cities, markets or roads) and biophysical (e.g. slope, precipitation) explanatory factors by means of multiple regression analysis (Veldkamp et al., 2001). Based on this analysis, each cell's suitability for the modelled land use types is determined. In the second step, land-use change is simulated by dynamic modelling of competition between the land-use types. Competitive advantage is based on the suitability values of a cell. Moreover land-use change is driven by changes of national level demand for each land-use type, for example as a result of population growth or an increasing crop production. This information is provided as exogenous variables.

In CLUE-S, the empirical statistical analysis is supplemented by decision rules that determine which land-use type is allowed to change in each simulation time step. With this element it is 
possible to restrict conversion from urban area to agriculture or to exclude nature conservation areas from land-use changes. Overmars et al. (2007) replace this empirical procedure for determining the cell suitability values by a deductive approach (Action in Context method) that models human decision making in terms of "options" and "motivations". The method is based on household surveys and applied in a case study for a municipality in the Philippines. Based on the suitability maps and the decision rules in combination with the actual land-use map, then CLUE-S calculates land-use change. This is done by an iterative procedure which allocates area demands for different land-use types to the best suited grid cells (Verburg et al., 2002). Similar to CLUE, changes of area demands are specified as exogenous driving variables which reflect underlying causes like population growth or changes of economic boundary conditions.

\section{Model concepts for the environment sub-system}

The CLUE framework does not explicitly represent processes of the environment sub-system. Nevertheless, different studies illustrate how the CLUE models can be combined with environmental models of different levels of complexity. For China, based on output of the large scale model version of CLUE, the effects of changes in rice cultivation area and livestock management on methane emissions were analysed (Verburg and Denier van der Goon, 2001) by using empirically derived emission factors (IPCC, 1997). Another example is presented by Priess et al. (2001). They couple a CLUE model with a spatial resolution of $9 \times 9 \mathrm{~km}$ to the NUTMON tool (Smaling and Fresco, 1993) for the assessment of soil nutrient balances in tropical agricultural systems. NUTMON is an input-output model that relates nutrient inputs such as fertilizer application and biological fixation to output fluxes in (among others) harvested products, crop residues and by gaseous losses. Moreover, Verburg (2006) couples the CLUE-S model to the process based LAPSUS model (Schoorl et al., 2004) in order to calculate the impact of land-use change on erosion erosion/sedimentation processes for a region in Southern Spain.

\section{Model integration}

The linkage of CLUE to the methane emission models is realized as a loose coupling approach where results from CLUE serve as input for further processing. In contrast, the coupling to the LAPSUS model is done by dynamically linking the models. In this example, erosion processes are influenced by agricultural management (e.g. tillage, changes in water infiltration and changes in vegetation cover). Erosion and sedimentation processes change the soil depth. This information on environmental change affects land-use decisions in the human sub-system. For example, when soil depth becomes too shallow to be productive or in case of the occurrence of gully-erosion a grid cell is evaluated as unsuitable for agriculture and consequently is abandoned. The case study shows significant differences between the simulated land-use patterns, compared to the results from simulations that neglect the environmental feedback.

\subsection{GEONAMICA framework}

\section{Model purpose and application}

GEONAMICA is a commercial application framework for constructing integrated models of the land system. It further elaborates the concepts on cellular automata based land-use modelling presented by White and Engelen (1997) and (Engelen et al., 1997). The framework supports spatial scale-hierarchies consisting of macro-levels (regional level) and spatial grids, with a resolution typically ranging from $100 \times 100 \mathrm{~m}$ to $500 \times 500 \mathrm{~m}$. Based on this framework, numerous regional integrated models have been developed for use as Decision Support Systems (Oxley et al., 2004; de Kock et al., 2001; MODULUS, 2000) and Policy Support Systems (van Delden et al., 2007).

Living Reviews in Landscape Research

http://www. livingreviews.org/lrlr-2008-1 
Examples are MODULUS (MODULUS, 2000; Oxley et al., 2004), which addresses physical, economic and social aspects of land degradation in the Mediterranean region, RamCo for coastal zone management in South Sulawesi in Indonesia (de Kock et al., 2001) and MedAction for the support of planning and policy making in the fields of land degradation, desertification, water management and sustainable farming in Mediterranean watersheds (van Delden et al., 2007). Sharing most features with Modulus, in the following the more recent MedAction system (van Delden et al., 2007) is chosen to illustrate the concepts of GEONAMICA-based models.

\section{Model concepts for the human sub-system}

Processes of the human sub-system are simulated by three model components: (1) water management, (2) land-use, and (3) crop choice and profit. The first component calculates water use of different land-use activities. The land-use model (Engelen et al., 1997) simulates land-use change on two different scale levels. On the regional level (macro-level), it calculates the land demands for different economic sectors such as agriculture, forestry and industry (de Kock et al., 2001) by representing a mixture of underlying causes such as demography and market mechanisms, according to Geist and Lambin (2002). These land demands are then spatially allocated to the grid level (micro-level). Here, land-use decision making is simulated by the constraint cellular automata approach introduced by White and Engelen (1997). As important factors for location choices, the model considers the cell's suitability for different types of land-use, its spatial neighbourhood, zoning restrictions and accessibility of transport infrastructure. In the next step, the crop choice and profit model is applied to determine the best suited crop type for each cell that has been classified as agricultural land before. This is done by portraying the decision making process on level of individual farmers, which among other factors regards farming history, yield and expected profits. While crop prices are provided as exogenous scenario variables, each cell's suitability for a particular crop is determined dynamically by analysing important soil and landscape parameters.

\section{Model concepts for the environment sub-system}

The environment sub-system consists of (1) a climate and weather model, (2) a hydrology and soil model and (3) a vegetation model. Simulations are performed on grid level with different temporal resolution. The climate and weather model regionalises data from meteorological stations and general circulation models to the grid level. In the hydrology model the processes interception, runoff, evapotranspiration, infiltration, soil moisture, aquifer recharge, river flow and transmission loss are implemented. Based on this information, together with soil characteristics such as texture and thickness, the model simulates processes of soil erosion and sedimentation as well as soil and aquifer salinity. The vegetation model consists of two elements. The plant growth element determines structural components of plants and crop yields. The natural vegetation element applies a rule-based approach for calculating succession processes and the response of natural vegetation to disturbances like fire. It determines the vegetation type for all grid cells that are not used by human activities like settlement and agriculture.

\section{Model integration}

The level of integration within and between the sub-systems is high. Within the environment sub-system, numerous feedback mechanisms are realized. For example, soil moisture as calculated by the hydrology model is used by the plant growth model for the simulation of biomass growth. The calculated biomass, in turn influences soil moisture due to the dependence of soil evaporation and transpiration on structural variables such as leaf area index and root biomass (van Delden et al., 2007). Feedback between the human and environment systems is realized for agricultural 
management. On the one hand management events such as sowing, ploughing, harvest and irrigation have a direct effect on crop growth. In turn, the computed crop yields influence the farmer's choice for a specific crop in the profit and crop choice model. If an agricultural cell is taken out of production, it changes back to natural vegetation over a defined time period.

\subsection{IMAGE model}

\section{Model purpose and application}

The Integrated Model to Assess the Global Environment (IMAGE 2.4) is not a specialized model for the global land system but a dynamic integrated assessment model that aims at the simulation of the major societal and environmental processes of the Earth System and their feedbacks (MNP, 2006; Alcamo et al., 1998). The model is designed for global level analysis with a time horizon of 100 years and operates on two different scale levels. A macro-level is defined by 24 world regions while the Earth surface is represented as a 30 arcminutes grid equalling a cell size of approximately $50 \times 50 \mathrm{~km}$ at the equator. IMAGE has been applied to calculate land-use emissions (Strengers et al., 2004) as well as impacts of land-use change on ecosystems and the environment on global (GEO, 2002; Leemans and Eickhout, 2004; Scenarios Working Group, 2005; Eickhout et al., 2006) and (in context of the EURURALIS project) on the continental level (Eickhout et al., 2007). IMAGE output in form of land-cover maps serves as input for different types of studies, ranging from bio-energy potentials (Hoogwijk et al., 2005; de Vries et al., 2007) to the assessment of the impacts of land-use change on the carbon balance of the terrestrial biosphere by coupling to the global vegetation model LPJ (Sitch et al., 2003; Müller et al., 2007).

\section{Model concepts for the human sub-system}

The human sub-system of the global land system is represented by three major model components which are driven by exogenous data on demographic and economic trends. (1) Energy supply and demand is simulated by the TIMER model for each world region. While the energy demand is estimated based on aggregated economic indicators such as GDP and household consumption, the supply side regards different technology paths of energy production. The model output includes information on energy consumption by different sectors such as residential or industry, the mix of energy carriers (coal, oil, gas, bio-fuels etc.) as well as on the resulting emissions of greenhouse gases. (2) Consumption and trade of agricultural products are calculated by the GTAP model. GTAP is an economic Computable General Equilibrium model (CGE) that takes into also account the impact of non-agricultural sectors on agriculture (van Meijl et al., 2007). (3) Finally, land-use change is calculated by a spatial allocation model on the grid level. The land-use decision making is formulated in a rule based manner and includes two steps. First, the suitability of each raster cell for agriculture and timber extraction is calculated, taking into account spatial neighbourhood to other land-use types, population density as well as potential crop yields and forest productivity. Then, the demand for agricultural and forest commodities (computed by GTAP and TIMER) as well as for bio-energy crops (computed by TIMER) is distributed to the best suited grid cells within each region, according to a set of heuristic "land allocation rules".

\section{Model concepts for the environment sub-system}

The environment sub-system consists of model components for terrestrial vegetation, terrestrial carbon and nutrient cycles, and biodiversity. All these components operate on grid level. The terrestrial vegetation part is further separated into a model to compute the potential distribution of natural vegetation and a model for potential crop yields, both taking into account local soil and climate conditions. Potential crop yields are computed with the global agro-ecological zones

Living Reviews in Landscape Research

http://www. livingreviews . org/lrlr-2008-1 
approach (Fischer et al., 2002) that uses both rule-based and process-based modelling techniques. The terrestrial carbon model simulates carbon fluxes between atmosphere and biosphere taking into account the impact of land-use change as well as climate change, represented by the processes of soil respiration and net primary production of natural vegetation. The nutrient cycle model computes the surface balances of phosphorus and nitrogen, including nutrient emissions to the atmosphere and to groundwater and surface water. It accounts for point sources like wastewater treatment as well as soil nutrient dynamics of agricultural soils (non-point sources). The impact of stress factors like climate and land-use pattern on biodiversity is assessed by the GLOBIO model (Nellemann et al., 2001). Being formulated as a statistical regression model, it is used to estimate the mean species abundance in relation to the species abundance in primary undisturbed vegetation.

\section{Model integration}

The model components of IMAGE are tightly coupled with feedback mechanisms between the different components and across scales. Within the human sub-system, for instance regional demands for agricultural commodities and bio-energy crops are provided to the land- use model by GTAP and TIMER. In turn, yields and yield changes due to climate change as well as information on the expansion of agriculture to less productive area are fed back to GTAP in order to calculate land supply curves (MNP, 2006). Regarding the environment sub-system, land use and the type of natural vegetation serve as input to the carbon cycle model while the land-use pattern and nutrient loadings have an impact on biodiversity. Aiming at the representation of the whole Earth System, IMAGE also models feedbacks between the land-system and the atmosphere-ocean system. For example, natural vegetation patterns and crop yields are influenced by climate parameters. At the same time, activities in the different land use (via the carbon model) and energy sectors produce greenhouse gas emissions (e.g. by deforestation or combustion processes) that contribute to climate change.

\subsection{ITE $^{2} \mathrm{M}$ model network}

\section{Model purpose and general design}

The ITE ${ }^{2} \mathrm{M}$ (Integrated Tool for Ecological and Economic Modelling) model network has been developed to simulate the functioning of complex human-environment systems and to evaluate the influence of changing land use on environmental services. ITE ${ }^{2} \mathrm{M}$ links interdisciplinary models, covering aspects of agro-economy, agricultural policy and environmental services (Fohrer et al., 2002; Frede et al., 2002; Reiher et al., 2006). Scale levels of $\mathrm{ITE}^{2} \mathrm{M}$ are specific to the model components, ranging from a $25 \times 25 \mathrm{~m}$ grid over fields to sub-catchment level. Its first application was for the "Lahn-Dill Bergland" region $\left(1200 \mathrm{~km}^{2}\right)$ in Germany. Simulation studies focus on the effects of changes in land-use policy and agricultural management on environmental services like economic output, water balance and biodiversity (Frede et al., 2002; Fohrer et al., 2001; Gottschalk et al., 2007).

\section{Model concepts for the human sub-system}

The human sub-system is modelled by the models ProLand (Möller et al., 1999; Kuhlmann et al., 2002) and CHOICE (Borresch and Weinmann, 2006). ProLand is a static bio-economic model to simulate the spatially explicit allocation of land-use systems for a specific point of time in the future, dependent on legal and economic boundary conditions, and environmental factors. Land-use systems include various types of cropland, grassland, forest and fallow systems whereas settlement area and infrastructure are assumed as static. For each decision unit (field level or $25 \times 25 \mathrm{~m}$ grid 
cell) the land-use system with the highest land rent is selected, assuming a profit maximizing behaviour of the land-owners. Land rent is calculated as the difference between profit and costs of production. While profit is defined as a function of potential yield, market prices and transfer payments, the cost side considers the land-use system specific labour and machinery costs, which are influenced also by local environmental factors like slope and soil clay content. The CHOICE model consists of two parts. First, the model evaluates landscape functions with an economic costbenefit approach. Model input is delivered by ProLand and the environmental assessment models described below. Then, a sub-model for agricultural trade (AGRISIM) calculates price effects of agricultural policies that serve as input for the ProLand model.

\section{Model concepts for the environment sub-system}

Processes of the environment sub-system are represented by the yield estimation module of ProLand and by different models used for the assessment of environmental services. ProLand uses yield information for cropland, grassland and forest to determine the income side of the land rent calculations. Potential yield is calculated for each grid cell with a Liebig production function, based on site conditions like soil, temperature, water and genetic potential (Kuhlmann et al., 2002). Models for environmental services cover aspects of hydrology, biodiversity and soil pollution. The ecohydrological model SWAT (Soil Water Assessment Tool, Arnold et al., 1993) is used to calculate the water balance and water quality on level of sub-catchments. Hydrological processes include potential evapotranspitration, surface run-off and soil percolation. Moreover, crop growth is computed by a stripped-down version of the EPIC-model (Williams et al., 1990). The biodiversity side is represented by the cellular automata model ANIMO for habitat specific species numbers and botanical species richness (Frede et al., 2002) and the GEPARD model for species richness of birds and carabids (Gottschalk et al., 2007). Reiher et al. (2006) also describes the application of the ATOMIS model to estimate the fate of heavy metals in top soils. These three models operate on the $25 \mathrm{~m}$ grid level.

\section{Model integration}

The linkages between the models within $\mathrm{ITE}^{2} \mathrm{M}$ are straight forward and do not account for feedback loops. ProLand computes land-use scenarios and serves them as input to the environmental assessment models. Based on the collected model results, CHOICE then evaluates the environmental services. Human-environment interactions are modelled by the yield module of ProLand that provides information to the decision making process. Furthermore the calculated land-use pattern influences biodiversity and the management activities associated to each land-use system (e.g. fertilizer input) have an effect on the water balance and quality as well as on crop growth as calculated by SWAT.

\subsection{LANDSHIFT model}

\section{Model purpose and application}

The aim of the LANDSHIFT model is to simulate land-use change dynamics on global and continental scale (Alcamo and Schaldach, 2006; Schaldach et al., 2006). It integrates functional components that represent human and environmental aspects of the land system. LANDSHIFT operates on a spatial scale-hierarchy that consists of three different levels: a macro-level defined by countries, an intermediate level (global 30 arcminutes grid) and a micro-level that is defined by a global 5 arcminutes grid. Currently there are two applications documented. First is a continental scale analysis on impacts of land use changes on the spatial extent of natural vegetation in Africa (Schaldach et al., 2006) and on future trends of the extent of irrigated areas (Heistermann, 2006). Second

Living Reviews in Landscape Research

http://www. livingreviews . org/lrlr-2008-1 
application is an analysis of the impact of bio-fuel development on country-wide land-use change in India (Schaldach et al., 2008).

\section{Model concepts for the human sub-system}

The human sub-system of the land system is represented by the land-use-change module (LUCmodule). Societal and economic data like population growth, production of agricultural commodities (crops and livestock) and yield increases are provided as exogenous variables to the module. In current studies, the Partial Equilibrium Model IMPACT (Rosegrant et al., 2002) is used to calculate agricultural production and crop yield changes for countries. The LUC-module determines the locations where land-use change takes place by regionalizing the country level demands for area intensive commodities and services to the micro-level, i.e. to the grid cells of the particular country. Land-use decisions are made by different sub-modules, each representing one land-use activity. Currently sub-modules for settlement (METRO), crop cultivation (AGRO) and grazing (GRASS) are implemented. Underlying model concept is a demand and supply approach. Each sub-module is responsible to allocate specific demands to the most suitable cells. The supply side is defined by the available land (number of grid cells) and the amount of a commodity that can be produced on the cell (e.g. crop yields, net primary productivity (NPP) of grassland). This information is calculated by "productivity modules" that are part of the representation of the environment sub-system (see below). Consequently, changes of land-use pattern are either induced by changes of the demand-side or by changes of local productivity. Regionalization is done in a two step procedure. Firstly, the suitability of each grid cell for a particular land-use type is determined by a multi-criteria analysis conducted by each sub-module (Eastman et al., 1995). The analysis considers sector-relevant landscape properties (e.g. biomass productivity and slope) as well as spatial neighborhood relations and socio-economic factors (e.g. population density and road infrastructure) in form of a linear utility function. Furthermore, land-use constraints like protection of nature reserves are taken into account. The second step is to allocate land within a particular land-use sector. For each sub-module, a specific allocation strategy is implemented. For instance, the allocation of different crop types on arable land (AGRO) is computed by a modified version of the Multi Objective Land Allocation Algorithm (Eastman et al., 1995) while METRO uses a rule-based approach to distribute new population to the raster cells. Competition between the land-use sectors is modelled by defining a hierarchy between the responsible sub-modules that reflects their economic importance. This results in the sequential execution, starting with METRO, followed by AGRO and GRASS.

\section{Model concepts for the environment sub-system}

Within LANDSHIFT, the environment sub-system is defined by productivity modules. They generate information on biomass productivity in terms of crop yields and grassland net primary production (NPP), on each 5 arcminutes raster cell under local climate, soil and management conditions. These data are used for suitability evaluation by the land-use sub-modules and also determine the potential local production (supply) for each agricultural commodity. Currently, these calculations are carried out by a grid version of the agro-ecosystem model DayCent (Parton et al., 1998; Stehfest et al., 2007), which has a detailed process-oriented representation of plant growth, soil water fluxes, soil carbon dynamics and nutrient pool dynamics. The model calculates global maps on a 30 arcminutes grid for yields of major crop types and for grassland which are mapped to the 5 arcminutes cells within the boundary of each 30 arcminutes cell. Calculations are conducted for 10-year time slices of climate change scenario data under country-specific crop management assumptions. Hence, data on crop management and climate variables are both exogenous driving variables to the model. 


\section{Model integration}

The model components of LANDSHIFT are coupled by a soft-link. Both productivity and economic data are calculated separately and then are provided as exogenous input variables to the LUCmodule. The link between the human and environment sub-system is established by the variable "biomass production", as it influences location choices for cropland and grazing. The crop yields generated by DayCent are adjusted each time step by the IMPACT model outcome on yield increases, which reflect improvements of agricultural management due to technological and societal change. Moreover, simulation results from the global hydrology model WaterGAP2 (Alcamo et al., 2003) on water availability are used as exogenous variable to determine suitable grid cells for the expansion of irrigated area (Heistermann, 2006). While between the components for the human and environment subsystem, feedback mechanisms are not implemented, yet, the internal structure of each component shows numerous complex feedback mechanisms. For example, the DayCent model represents feedbacks between the different parts (e.g. vegetation and soil) of the modelled ecosystem, while the LUC-module simulates competition between the different land-use sectors in dependence on the actual spatial land-use pattern.

\subsection{Patuxent Landscape Model (PLM)}

\section{Model purpose and application}

The Patuxent Landscape Model (PLM) is an integrated modelling framework to simulate ecosystem processes on the watershed level and their linkages to human factors (Voinov et al., 1999a; Costanza et al., 2002). The model operates on a grid with a cell size ranging from $200 \times 200 \mathrm{~m}$ up to $1 \times 1 \mathrm{~km}$. It has been developed for the Patuxent River watershed in the State of Maryland in the U.S., in order to address problems of water quality management. Principal aims of the model are to develop a better understanding of the complex interactions between human and natural systems and to serve as a predictive policy tool for supporting environmental management efforts to improve water quality by reducing nutrient loading resulting from land use. Results from a scenario analysis which capture the impact of land-use change as well as of changes in agricultural management practice are presented by Costanza et al. (2002).

\section{Model concepts for the human sub-system}

The human sub-system is modelled by an economic model which computes the probability of conversion from agriculture or forest to residential land use within the seven counties of the Patuxent River watershed. It models the decision making process with a Markov Chain approach, interpreting the Markov transition probabilities as discrete choice probabilities (Bockstael, 1996). As decision criteria the model applies the value of a grid cell for different types of land use, based on factors like distance to public infrastructure and proximity to other land-use types as well as on historical land conversion decisions and land conversion costs. Model output is the likelihood of land-use conversion for each grid cell. The result is interpreted as the spatial pattern of development pressure (Voinov et al., 1999a). The actual quantity of land-use change is then computed by combining these probability maps with assumptions of regional growth pressure for settlement development, defined as part of the scenarios, for example as number of new housing units in the future (Costanza et al., 2002). In PLM the aspect of land management practices of agricultural and residential land use and its impacts on the environment, which, in context of this review, we understand as a part of the human sub-system, is modelled within the "ecological component" by the "human dominated systems" sub-model (see below).

Living Reviews in Landscape Research

http://www. livingreviews.org/lrlr-2008-1 


\section{Model concepts for the environment sub-system}

The environment sub-system is described by the "ecological component" which includes a grid level model and a spatial model. The grid level model (unit model) simulates ecological processes for the local "habitat type" (Costanza et al., 2002) like forest, cropland, grassland, urban and open water within each grid cell. It builds on the General Ecosystem Model (GEM) by Fitz et al. (1996) and beside the sub-model for "human-dominated systems" includes 3 other linked sub-models (Costanza et al., 2002) to describe the different functional parts of an ecosystem. (1) The hydrology sub-model computes vertical water fluxes within each cell including infiltration, transpiration and evaporation. (2) The nutrient sub-model simulates the dynamics of phosphorus and nitrogen. It models plant uptake and soil processes like organic matter decomposition. (3) The macrophyte sub-model simulates processes of plant growth for different habitat types (both in aquatic and terrestrial environments) in response to temperature, nutrient levels and water availability. The unit models are connected by the spatial model which is responsible for computing horizontal fluxes of water and the associated nutrient fluxes between the grid cells (Voinov et al., 1999b).

\section{Model integration}

PLM is characterized by a high level of integration. It models complex inter-linkages between hydrology, plant growth and nutrient cycling as well as between the human sub-system and the environmental sub-system. The model considers land-use conversion as well as land-use modification in the agricultural sector by changing management practices, realized by the "human-dominated system" model component. This component acts as an interface between the human and the environment sub-system. While agricultural land use affects plant growth and nutrient dynamics by fertilizer input, planting, harvesting and crop rotations (Binder et al., 2003), residential land use has an effect both on surface run-off (hydrology) and nutrient loading by road run-off or point sources like discharges from septic tank of households, located within the watershed.

\subsection{SITE model}

\section{Model purpose and application}

The SITE modelling framework (Simulation of Terrestrial Environments) is a spatial explicit integrated land-use model, developed for studies at the regional scale. The model is driven by demographic, economic, and climatic dynamics and by demands for spatially relevant commodities, such as agricultural and forest products and space for housing and commerce. SITE provides generic land-use modelling functionalities to implement different case studies. The Sulawesi case study, for example is covering $7,200 \mathrm{~km}^{2}$ and employs a spatial resolution of $250 \mathrm{~m}$ (sub-region) or $500 \mathrm{~m}$ (Priess et al., 2007a; Mimler and Priess, 2008). SITE allows for a multi-scale approach, e.g. implementing different spatial scales to simulate the study region in Indonesia (sub-districts, communities, grid cells). Additional important spatial units such as catchments, protected areas, or preference zones are implemented and may crosscut other spatial units such as administrative boundaries. According to Priess et al. (2007b), the major purpose of SITE is to serve as a scientific tool in scenario analysis, to study socio-economic and environmental impacts of land-use dynamics and some of their important feedback mechanisms. Secondly, SITE is used to simulate stakeholder perceptions of perceived future opportunities and challenges, and to inform stakeholders and decision makers of the impacts of potential pathways of change (Priess et al., 2007b). In order to match the scientific purposes, the land-use module is dynamically coupled to biophysical models, which are simulating crops, natural vegetation (Parton et al., 1998) and changes in pollinator diversity (Klein et al., 2003). The biophysical models inform the land-use module of changes in for example crop productivity. This information is used (i) to calculate economic and environmental indicators 
and (ii) to adjust suitability and allocation 'decisions' in subsequent time steps. Model parameters without sufficient empirical basis can be calibrated using genetic algorithms and map comparison algorithms, which are implemented in additional components of the modelling framework (Mimler and Priess, 2008).

\section{Model concepts for the human sub-system}

The modelling framework can represent an arbitrary number of behavioural rules, including different types of decision makers. The complexity of the rules and the degree of detail represented, depend on (i) the purpose of the study, (ii) the availability of empirical descriptive information (regional preferences and believes; management of crops, etc), and (iii) structural information on decision makers and the decision making processes. In the Indonesia case study, the human component is represented as an 'average decision maker', implemented as a set of decision rules and constraints, e.g. with respect to the types of land-use conversions that are possible. Based on a multi-criteria analysis, which is carried out separately for every land-use type and every grid cell, a ranking of suitable cells is calculated. After the suitability analysis, the SITE model allocates demands for all commodities in a hierarchical fashion. This task is carried out by the allocation modules, which check (i) whether a cell is eligible for land-use change, (ii) which is the optimal land use for the present cell, and (iii) whether the transition from one land-use type to another is permitted. For example, cells recently converted to crops carrying high establishment costs like coconuts or cocoa, can only be converted after 15 years, and thus would not be eligible for change for example after 4 years. Additionally, the suitability of the new land-use type needs to surpass the suitability of the current type (i) to a predefined amount and (ii) for a number of years specific to each land-use type, mimicking the conservative behaviour of farmers. The allocation hierarchy is based on regional allocation priorities. Competition of different land-use types (for example crops) for favourable locations is simulated explicitly by the allocation algorithm, which identifies the local optima for all land-use types based on their overall suitability.

\section{Model concepts for the environment sub-system}

The biophysical environment is represented by either static maps (elevation, rivers), or dynamic maps (soil parameters, land cover), which are updated every simulated annual time step. The dynamics of natural vegetation and crops are represented by different, partly modified modules of the DAYCENT model (Parton et al., 1998; Stehfest et al., 2007), which simulates plant growth, the production of crop yields and resulting changes in soil parameters in daily time steps. Like other models, DAYCENT employs several component models to simulate different processes such as evapotranspiration and runoff, nutrient uptake and turnover, but also agricultural management in terms of irrigation, fertilisation and ploughing. Output of the DAYCENT model is usually aggregated to monthly or annual values and transferred to the land-use model. Weather and crop management data, which are required to drive the DAYCENT model, are read from a scenario database. An additional component simulates the biodiversity of certain groups of organisms, currently based on an empirical model (Klein et al., 2003).

\section{Model integration}

One of the novel features of the SITE modelling framework is the close coupling of the simulated environmental or biophysical dynamics and the decision making. As a consequence, the simulated decision makers can take environmental changes into account, irrespective whether they are caused by the simulated use and management of the land (e.g. intensification of agriculture or overexploitation) or by global change processes. Similarly, the simulated decision makers are informed about land-use related changes in biodiversity, e.g. of pollinators. The current version of SITE uses

Living Reviews in Landscape Research

http://www. livingreviews.org/lrlr-2008-1 
the (negative) impact on crop yields as a feedback, because it is known that changes in biodiversity as such are not meaningful to Indonesian farmers, whose reasoning and decision making are simulated. SITE calculates a number of environmental indicators (land-cover change, productivity of natural vegetation, soil fertility, trace gas emissions, etc.) and socio-economic indicators (crop yields, gross margins, land-use change, encroachment of protected areas, etc.), providing an integrative insight into land-use dynamics and their potentially beneficial or detrimental consequences for society and environment.

\subsection{SYPRIA model}

\section{Model purpose and application}

SYPRIA (Southern Yucatán Peninsular Region Integrated Assessments) is a spatially explicit model to simulate scenarios of land-use change in the Southern Yucatán Peninsular region $\left(\sim 22.000 \mathrm{~km}^{2}\right)$ of Mexico. SYPRIA falls into the class of agent-based models (Parker et al., 2002). It is a probabilistic model that produces likelihoods of change. Consequently a large number (100-160) of Monte Carlo runs is needed to produce stable results (Manson, 2006). Conceptually, the model consists of three components: actors, institutions and environment. Spatial scale levels are administrative units (ejidos) and an underlying $28 \times 28 \mathrm{~m}$ grid, which reflects the unit of observation of the applied satellite imagery from the Thematic Mapper sensor (Turner II et al., 2001). The goals of the model are to examine links between land manager decision-making strategies and environmental and institutional factors, and furthermore to explore scenarios that relate to land use, population growth, agricultural systems and institutional influences on household decision making (Manson, 2005). Results from a scenario analysis are presented by Manson (2006). The described scenarios concentrate on the influence of population growth on the quantity of land-use change and on the influence of cultivation strategies (shifting cultivation vs. market oriented) and land tenure policies on the location of land-use change.

\section{Model concepts for the human sub-system}

The human sub-system is represented by actors (smallholder households) and institutions as proxy for social systems (Manson, 2005). Both are implemented as software-agents. Land-use decisions are made by the actor-agents on grid level and are influenced by the boundary conditions and constraints computed by institution agents and by the local environmental conditions. Each actor-agent makes location decisions for different agricultural activities (e.g. the cultivation of subsistence or commercial crops). The land-demand of each household for these activities is defined probabilistically within a certain range by an institutional agent (see below). Land-use change is computed in two steps. First, each actor-agent determines the suitability of each raster cell using multi criteria evaluation by a linear utility function in addition with Boolean constraints (Eastman et al., 1995). Utility factors include environmental factors on grid level like soil quality and distance to roads and markets. Constraints consider land-use limitations that are provided by institutions (see below). In the second step, each household chooses a number of cells to fulfil its land demand by maximizing the aggregate suitability. Here, each household is characterized by an individual location choice strategy (specific weights for the utility factors). These decision strategies are computed by genetic programs based on location data obtained for a calibration period. Actor decision making is influenced by institution-agents that define boundary conditions and constraints. A population-agent is responsible for the number of active actor-agents in each ejido, dependent on the observed population density and the future population growth. Agents on the ejido-level assign land demands to households (see above) and define spatial constraints for actor land-use decisions by preventing forest and natural reserves from agriculture and by deciding 
whether actor-agents are allowed to locate their land demand outside their home ejido. Furthermore, a market-agent makes available to all actors travel-cost surfaces for markets, population centres and roads.

\section{Model concepts for the environment sub-system}

A generalized cellular automata model is used to simulate the environment sub-system on grid level. Implemented processes include changes in soil fertility and vegetation succession. Both are defined by transition rules. According to Manson (2006), the change of soil fertility depends on land cover and soil fertility of the past time step, the soil type with respect to its value for agriculture, the duration of the cells' current land-use type and the amount of fertilizer applied by actoragents. Moreover, vegetation succession is calculated as the transition between different succession stages, taking into account the time since the last transition, the total number of neighbouring cells acting as seed sources and the fallow cycle dynamic that affects soil fertility. Other parts of the environment, which are relevant for actor decision making, like elevation, terrain slope and precipitation are treated as static variables.

\section{Model integration}

As institutions primarily provide constraints and boundary conditions for the actors, there is no feedback from actor decision making implemented. In contrast, the actor and environment components are tightly coupled. The effects of land use on environmental properties like changes of soil fertility by agricultural management and on natural vegetation (fallow cycle) directly feed back to the actor decision making process. For instance, decreasing soil fertility due to long term crop cultivation without additional fertilizer use makes a grid cell less attractive for further agricultural use. 


\section{Discussion: Modelling of the land system}

In this paper, eight integrated model approaches were reviewed. We found that a large variety of techniques with different levels of complexity were used to simulate the processes of the human-environment system and feedback between the sub-systems. Table 2 summarizes the main characteristics of the models. In allusion to the review criteria, this section addresses commonalities and differences between the models in respect of their representation of the key elements of land systems (i.e. human sub-system, the environment sub-systems and the linkages between them). In addition, questions of model application and adaptation to new geographic regions are discussed.

\subsection{Representation of the human sub-system}

Most of the reviewed models concentrate on the simulation of local land-use decisions and the resulting changes of the spatial land-use pattern (proximate level) and do not explicitly model processes on the underlying level. Instead regional or global demographic and economic developments are exogenous variables for the decision making process, for example in form of demands for housing area (PLM), policies and planning regulations by payments of subsidies ( $\mathrm{ITE}^{2} \mathrm{M}$ ) or land-use restrictions on natural conservation areas (CLUE, LANDSHIFT, SITE). Among the three examples that explicitly model processes on the underlying level (IMAGE, SYPRIA and GEONAMICA) only IMAGE includes feedback mechanisms from the local level to the regional level. This feedback is realized by land supply curves that are employed to indicate scarcity of suitable agricultural land which affects the calculation of regional agricultural demands by the GTAP model.

A major difference between the models is the level of land-use decision making. Verburg et al. (2006a) distinguish between individual entities (people) and grid cells (pixel) as reference units for land-use decisions. The reviewed models cover a wide range of different approaches which fall between these extremes. We only found one agent based model (SYPRIA) that puts the "people" in the centre of interest by modelling the land-use related decisions of households and institutions. This may be explained by the comparatively high data demands of models that very explicitly represent human decision making (e.g. SYPRIA requires detailed data from household surveys). Contrastingly, CLUE, IMAGE, GEONAMICA and $\mathrm{ITE}^{2} \mathrm{M}$ strictly focus on grid cells (pixels) as decision units. LANDSHIFT and SITE implement an intermediate level of complexity. They distinguish between land-use activities as aggregated decision makers with different behaviour, which are competing for available land-resources, in ways that may differ between simulated subregions or countries.

Regarding the procedure of modelling land-use change, we found that with the exception of $\mathrm{ITE}^{2} \mathrm{M}$ in which decisions are made individually for each grid cell (or land parcel) all the reviewed models (also the agent based SYPRIA) can be categorized as top-down approaches (Verburg et al., 2006a). The first simulation step is an analysis of the suitability of each raster cell for the modelled land-use types. This is done either by methods from economic theory such as cost-benefit analysis $\left(\mathrm{ITE}^{2} \mathrm{M}\right)$ and logit models (PLM), by means of multi-criteria analysis (GEONAMICA, IMAGE, LANDSHIFT, SITE, SYPRIA) or by statistical regression (CLUE). In the second step, rule based and heuristic approaches (IMAGE, LANDSHIFT, SITE) as well as cellular automata (GEONAMICA) and iterative procedures (CLUE) are used to translate the demand either for area of different land-use types (CLUE, GEONAMICA, SYPRIA) or the amount of different commodities (IMAGE, LANDSHIFT, SITE) to a spatial land-use pattern. While the majority of models do at least in a simple way account for scale effects, in that they include more than one spatial level (e.g. region and grid), spatio-temporal hierarchies or lag-effects such as the question "how fast and to which degree does land use change, when one or more drivers have changed" are either ignored, or represented in a static manner (e.g. in CLUE-S, SITE). 
The number of actively modelled land-use types depends on the scientific goals of the case study that the respective models are applied to. The potential of handling an arbitrary number of land-use types is given by the GEONAMICA and the SITE frameworks (which are rule-based models) and by the CLUE approach (mainly based on regression analysis). In other models, landuse types are associated to specific a decision making process (e.g. residential area in PLM or cropland in SYPRIA). These models cover a much smaller number of "active" land-use types but at the same time support a more differentiated representation of decision making processes. On the other hand, for each additional "active" land-use type, a dedicated decision making process has to be programmed and included into the respective model.

\subsection{Representation of environmental processes}

In the models reviewed, we identified different levels of complexity of modelling the environment sub-system. The rule-based cellular automata approach in SYPRIA and empirical models for crop yields in IMAGE and $\mathrm{ITE}^{2} \mathrm{M}$ are contrasted by process-oriented models. For instance, LANDSHIFT, PLM and SITE use very detailed ecosystem models (DayCent or GEM), whereas GEONAMICA achieves a similar degree of complexity by linking separate components for soil, hydrology and vegetation. Under the perspective of a clear model formulation, problems arise when environmental processes are represented not uniquely within a model or when processes are only poorly connected. In these cases, environmental variables are calculated by different methods which may lead to inherent inconsistencies in the model results. We found an example for the redundant formulation of an ecosystem process in $\mathrm{ITE}^{2} \mathrm{M}$. Here, the ProLand model component uses an empirical approach (Liebig function) to calculate crop growth while the same process is simulated by the EPIC model within the hydrology component. An example for poorly connected processes can be found in the current IMAGE model, where the global nitrogen cycle is modelled independently from vegetation and carbon dynamics.

Another important finding was that most of the reviewed integrated models limit their representation of the environment on "point processes". For this task they employ ecosystem models that operate on grid level and do not account for horizontal matter and energy fluxes between grid cells (SITE, GEONAMICA, IMAGE). Horizontal water fluxes (e.g. river discharge) are only simulated by the PLM model. ITE ${ }^{2} \mathrm{M}$ and LANDSHIFT also use complex hydrological models but in a loosely coupled fashion. These results indicate that the potential of using the reviewed models in context of water resources related research (e.g. questions of water availability and water quality) is only marginally explored, yet. 


\begin{tabular}{|c|c|c|c|c|c|c|c|c|}
\hline 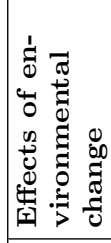 & 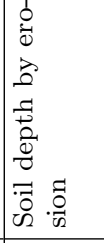 & \begin{tabular}{|l}
$\frac{n}{2}$ \\
0 \\
0 \\
0 \\
2 \\
0 \\
0 \\
0 \\
0
\end{tabular} & 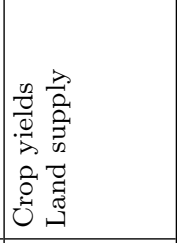 & $\begin{array}{l}\frac{n}{0} \\
\frac{0}{0} \\
\frac{1}{5} \\
0 \\
0 \\
0 \\
0\end{array}$ & 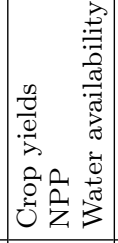 & & $\begin{array}{l}\frac{n}{0} \\
\frac{0}{0} \\
\frac{1}{2} \\
0 \\
0 \\
0 \\
0\end{array}$ & 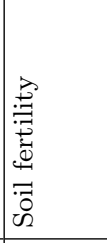 \\
\hline 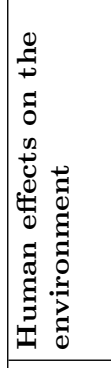 & 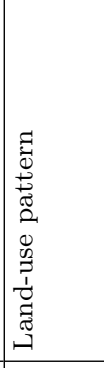 & 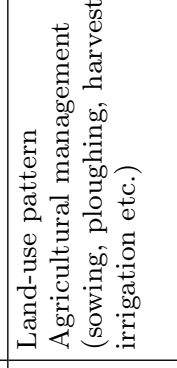 & 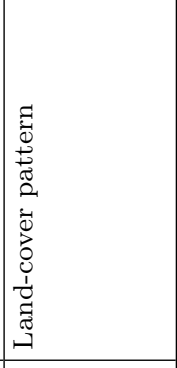 & 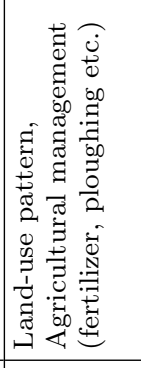 & 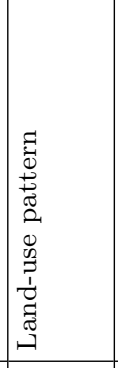 & 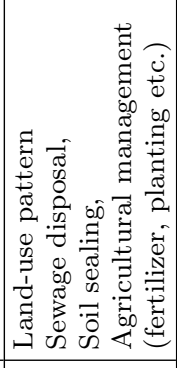 & 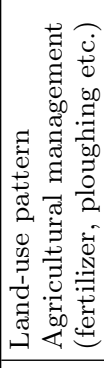 & 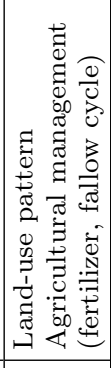 \\
\hline 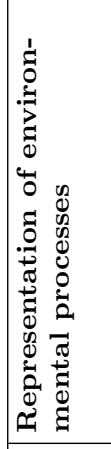 & 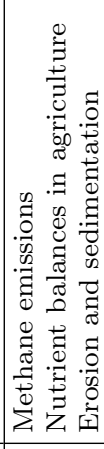 & 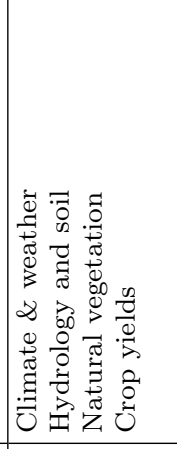 & 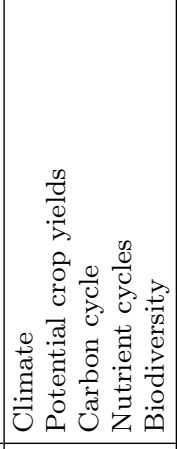 & 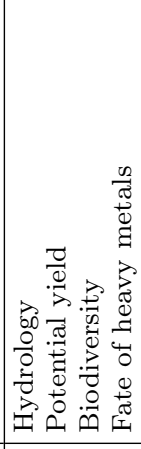 & 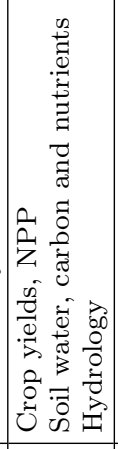 & 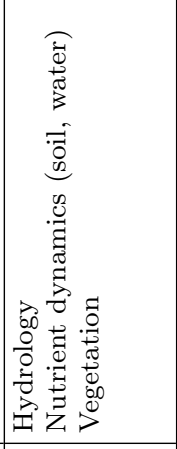 & 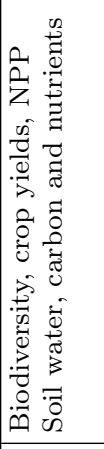 & 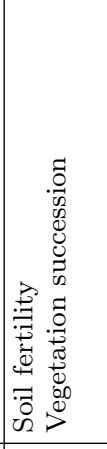 \\
\hline 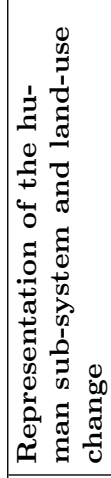 & 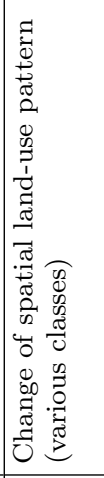 & 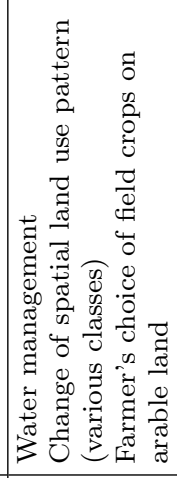 & 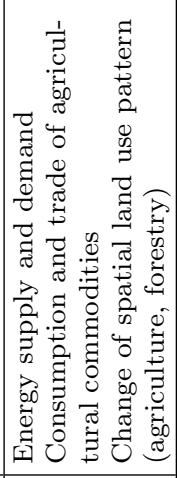 & 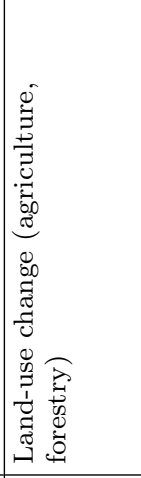 & 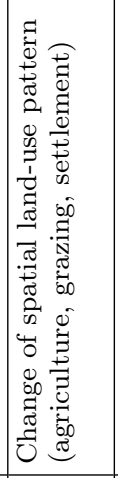 & 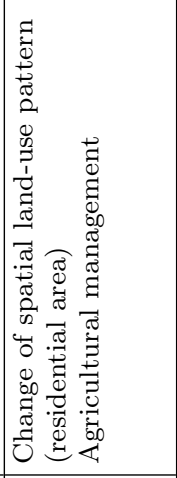 & 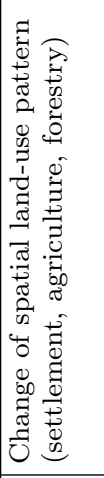 & 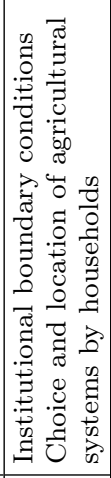 \\
\hline 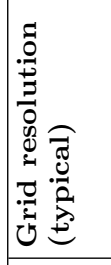 & 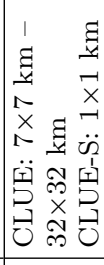 & 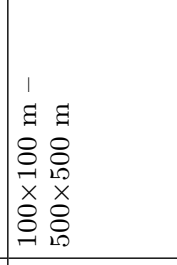 & 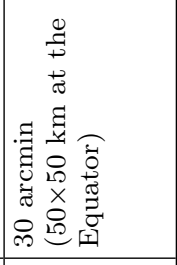 & 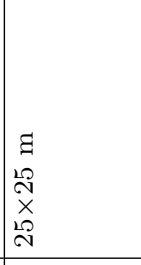 & 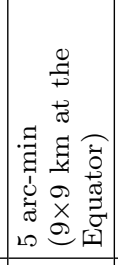 & 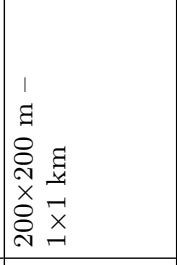 & 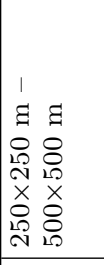 & \begin{tabular}{|l}
$\Xi$ \\
$\infty$ \\
$\widetilde{\alpha}$ \\
$\widetilde{\alpha}$ \\
$\sim$ \\
$\sim$
\end{tabular} \\
\hline $\begin{array}{l}\overrightarrow{0} \\
\overrightarrow{0} \\
\Sigma\end{array}$ & 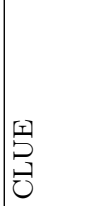 & 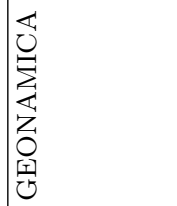 & 侄 & 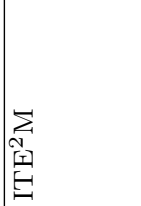 & 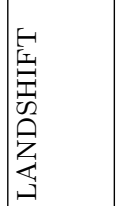 & & 国 & 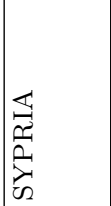 \\
\hline
\end{tabular}




\subsection{Model integration}

The link between the human and the environment sub-system is modelled via the effects of changing land-use patterns and the associated management actions on environmental factors and processes. Examples for the effects of changing land use patterns cover impacts on biodiversity (ITE ${ }^{2} \mathrm{M}, \mathrm{SITE}$ ) and on hydrological parameters (LANDSHIFT, ITE ${ }^{2} \mathrm{M}$ ). Modelling approaches to quantify the influence of the associated land management on the environment concentrate on the agricultural sector (soil fertility, crop growth, nutrient input). Effects of urbanization on water quality and surface run-off are only addressed by PLM. The potential effects of other types of land management for example in the forestry sector (in terms of management practices beyond deforestation) or in the field of nature conservation are addressed by none of the models. The same holds true for the modelling of effects of water use on available water resources (see last paragraph).

An important process for the agricultural sector, which is modelled very differently, is agricultural intensification, which is considered a key issue in land-use modelling by Lambin et al. (2000). In CLUE, the effects of intensification are modelled indirectly by changing the exogenous area demands for cropland, while IMAGE and LANDSHIFT use correction factors to account for yield changes due to technological change over time. On the other hand, approaches that explicitly model intensification processes are limited to the simulation of expansion of irrigated area (LANDSHIFT) and to the simulation of future trends of fertilizer application rates affecting crop productivity (PLM, SITE). A major limitation for the latter example is the lack of solid spatially explicit data on fertilizer use (Costanza et al., 2002). Other means of intensification such as genetic manipulated crops or pesticide application are not taken into account by any of the models.

A central element of the conceptual model of land systems are feedback effects of environmental change (caused by human activities) on the human system. Which feedbacks are implemented strongly depends on the model purpose. Most of the reviewed models again concentrate on the links between agricultural management and their effects on changes of land productivity. These effects are modelled as soil degradation (erosion), changes of soil fertility or changes of crop productivity, and feed back both on the suitability assessments and on the land allocation procedures. The only examples for linking data on changes in biodiversity to human decision making can be found in $\mathrm{ITE}^{2} \mathrm{M}$ and SITE. From these examples it becomes obvious that at the moment only a rather limited number of the possible environmental change impacts on human systems are covered by the individual models. Even more important is the fact that there is a significant lack of studies that systematically explore the influence of the implemented feedback effects on the model behaviour. The only attempt that we could identify is the publication by Verburg (2006).

\subsection{Model application and adaptation to other geographic regions}

The application of the reviewed models is predominantly in the context of scenario analysis with emphasis on the quantity and location of land-use change and the effects on environmental services such as crop yields, water quality, biodiversity and soil quality. In contrast, only GEONAMICA is explicitly addressed as Decision Support System. Types of scenario analysis include the comparison of different future pathways defined by the trends of exogenous driving variables such as population or economic development as well as the analysis of specific policy (tax) and land management options such as agricultural intensification in terms of fertilizer input and/or irrigation (ITE ${ }^{2}$ M, LANDSHIFT, PLM, SITE, SYPRIA). A major difference in the underlying modelling philosophy of land-use changes either based on inductive (e.g. statistical regression models like CLUE) or deductive approaches (e.g. rule based like SITE) imply different possibilities for the use in context of a scenario analysis. Concerning the time horizon of a scenario analysis, inductive approaches make long-term projections difficult (Verburg and Denier van der Goon, 2001), since the empirical relationships cannot necessarily be assumed to be constant over long time periods. This shortcoming is potentially overcome by deductive approaches that explicitly model the inter-

Living Reviews in Landscape Research

http://www. livingreviews.org/lrlr-2008-1 
action between underlying drivers of land-use change and decision making processes. They allow the modelling of changes over time in these relationships as part of the scenario assumptions and therefore increase their suitability to model the changing dynamics of land systems over a longer time period. Nevertheless time dependency of decision making is targeted by none of the reviewed models in a sufficient way, yet. As most of the models do support this feature, we see great potential for the models in the development of more differentiated scenario experiments.

Regarding the possibility to adapt the integrated models to other geographic regions, we have to distinguish between the large scale models IMAGE and LANDSHIFT which can be applied globally for any study region, like (large) countries or catchments, and the models predominantly used on the regional and watershed-level. The analysis of the latter ones shows that SYPRIA and ITE ${ }^{2} \mathrm{M}$ are developed specifically for single case studies. Here, particularly the modules representing the human sub-system require very specific data for defining household decision strategies (based on data from household surveys) or for economic data to describe cost structures of agricultural production systems. This extensive data demand makes it difficult to transfer these models to other study regions or scale levels.

In contrast, the CLUE, GEONAMICA and SITE are designed as frameworks that support the construction of region specific model applications, though with very different means. The CLUE team at Wageningen University provides information of how to adapt their model framework. Nevertheless the framework definition is limited to the land-use component. The GEONAMICA framework, as a rule-based system, among other factors, relies strongly on the positive or negative spatial interaction of all simulated land-use types and provides several user interfaces to adjust amplitudes and distances of spatial interactions, and other model parameters. Furthermore, it provides a consistant technical framework for the integration of both human and environment models in the form of so called "Model Building Blocks". Finally, SITE provides a generic landuse modelling framework, for which case study specific rule-sets can be developed in the widely used scripting language Python, e.g. based on existing applications. It also offers technical solutions to couple different model components. 


\section{Conclusion}

Despite the large number of available land-use change models, approaches for regional to global scale land systems which include the key elements of both the human and the environment subsystem, are scarce in literature. One reason is the levels of complexity and interactions that need to be represented by this type of models (which is also reflected in the large number of person months required for their development). The reviewed models all have their individual strengths, but are still limited in their ability to simulate all the complexities involved in the functioning of land systems. Based on the discussion in the last section, we have identified five major areas where future research activities should focus on.

- The first area is the improvement of model components for land-use decision making in order to facilitate more differentiated scenario analysis (i.e. in the main field of application of the reviewed models). Open research questions on for large scale include the simulation of changes of decision making mechanisms over time, the spread of innovation in terms of agricultural management practices and the influence of national or international institutions on land-use decision making. Here, future research can build upon experience and techniques from the field of agent-based modelling.

- There is also need to develop a deeper understanding of feedback effects on the model behaviour. In this context, a central question for further research will be the development of methods for testing and validating these highly integrated models.

- On the spatial scales which are subject of this review most models focus on the spatially dominant land-use and land cover types such as agriculture. Future studies should pay more attention to processes related to urbanisation which is recognized as an important driver for environmental change (Grimm et al., 2008).

- Currently, almost exclusively the effect of agricultural management on the environment is taken into account by the reviewed models. It will be a major step forward to incorporate more detailed representations of forest and water management. This will open up many new fields of model applications.

- Finally, on a more technical level we propose to investigate the application of open software frameworks such as OpenMI (Gregersen et al., 2007) to support integrated model building and to facilitate the exchange of model components between research groups. 


\section{References}

Achard, F., Eva, H.D., Mayaux, P., Stibig, H.-J., Belward, A. (2004), "Improved estimates of net carbon emissions from land cover change in the tropics for the 1990s", Global Biogeochemical Cycles, 18, GB2008, doi:10.1029/2003GB002142. 1

Agarwal, C., Green, G.M., Grove, J.M., Evans, T.P., Schweik, C.M. (2002), "A review and assessment of land-use change models: dynamics of space, time, and human choice", Gen. Tech. Rep., NE-297, Newton Square, PA (U.S. Department of Agriculture, Forest Service, Northeastern Research Station). URL (cited on 20 March 2008):

http://www.treesearch.fs.fed.us/pubs/5027. 1

Alcamo, J., Schaldach, R. (2006), "LandShift: Global Modelling to Assess Land Use Change", in EnviroInfo 2006: Managing Environmental Knowledge, (Eds.) Tochtermann, K., Scharl, A., Proceedings of the 20th International Conference 'Informatics for Environmental Protection', Graz, Austria, 6-8 September 2006, pp. 223-230, Aachen (Shaker). 1, 3.5

Alcamo, J., Leemans, R., Kreileman, E. (1998), Global Change Scenarios of the 21st Century Results from the IMAGE 2.1, Oxford, U.K. (Elsevier Science). 1, 3.3

Alcamo, J., Döll, P., Henrichs, T., Kaspar, F., Lehner, B., Rösch, T., Siebert, S. (2003), "Development and testing of the WaterGAP 2 global model of water use and availability", Hydrological Sciences Journal, 48: 317-337, doi:10.1623/hysj.48.3.317.45290. 3.5

Angelsen, A., Kaimowitz, D. (1999), "Rethinking the Causes of Deforestation: Lessons from Economic Models", World Bank Research Observer, 14(1): 73-98. URL (cited on 20 March 2008): http://ideas.repec.org/a/oup/wbrobs/v14y1999i1p73-98.html. 1

Arnold, J.C., Allen, P.M., Bemhardt, G. (1993), "A comprehensive surface-groundwater flow model", Journal of Hydrology, 142: 47-69, doi:10.1016/0022-1694(93)90004-S. 3.4

Balkhausen, O., Banse, M. (2004), "Modelling of Land Use and Land Markets in Partial and General Equilibrium Models: The Current State, Institute of Agricultural Economics", Working Paper Series of the Joint Research Project, Lund (IDEMA/SLI). URL (cited on 20 March 2008): http://www.sli.lu.se/IDEMA/WPs/IDEMA_deliverable_3.pdf. 1

Binder, C., Boumans, R.M.J., Costanza, R. (2003), "Applying the Patuxent Landscape Unit Model to human dominated ecosystems: the case of agriculture", Ecological Modelling, 159: 161-177, doi:10.1016/S0304-3800(02)00276-4. 3.6

Bockstael, N.E. (1996), "Modeling Economics and Ecology: The Importance of a Spatial Perspective", American Journal of Agricultural Economics, 78: 1168-1180. 3.6

Borresch, R., Weinmann, B. (2006), "Modellierung und Bewertung der entkoppelten Direktzahlungen - eine Anwendung des Landnutzungsmodells ProLand sowie des Bewertungs- und Modellrahmens CHOICE", in Good Governance in der Agrar- und Ernährungswirtschaft, Proceedings 46. Jahrestagung der Gesellschaft für Wirtschafts- und Sozialwissenschaften des Landbaus (GeWiSoLa), 04.-06. Oktober 2006, Giessen, Germany, Gießen (Justus-Liebig-Universität Gießen). URL (cited on 20 March 2008):

http://www . uni-giessen.de/gewisola2006/pdf/Borresch_Weinmann_korri.pdf. 3.4

Clarke, K.C., Hoppen, S., Gaydos, L. (1997), "A self-modifying cellular automaton model of historical urbanization in the San Francisco Bay area", Environment and Planning B: Planning and Design, 24: 247-261, doi:10.1068/b240247. Related online version (cited on 20 March 2008): http://www.geog.ucsb.edu/ kclarke/Papers/clarkehoppengaydos.pdf. 1 
Costanza, R., Voinov, A.A., Boumans, R., Maxwell, T., Villa, F., Wainger, L., Voinov, H. (2002), "Integrated ecological economic modelling of the Patuxent River watershed, Maryland", Ecological Monographs, 72(2): 203-231, doi:10.1890/0012-9615(2002)072[0203:IEEMOT]2.0.CO;2. 1, $3.6,3.6,3.6,4.3$

Couclelis, H. (1997), "From cellular automata to urban models: new principles for model development and implementation", Environment and Planning B: Planning and Design, 24: 165-174, doi:10.1068/b240165. 1

de Kock, J.-L., Engelen, G., White, R., Wind, H.G. (2001), "Modeling land-use change in a decision-support system for coastal-zone management", Environmental Modeling \& Assessment, 6: 123-132, doi:10.1023/A:1011587222253. 1, 3.2, 3.2

de Vries, B.J.M., van Vuuren, D.P., Hoogwijk, M.M. (2007), "Renewable energy sources: Their global potential for the first half of the 21st century at the global level: An integrated approach", Energy Policy, 35(4): 2590-2610, doi:10.1016/j.enpol.2006.09.002. 3.3

Eastman, J.R., Weigen, J., Kyem, P.A.K., Toledano, J. (1995), "Raster Procedures for MultiCriteria/Multi-Objective Decisions", Photogrammetric Engineering 85 Remote Sensing, 61(5): 539-547. Related online version (cited on 20 March 2008):

http://www . asprs.org/publications/pers/scans/1995journal/may/1995_may_539-547. pdf. $3.5,3.8$

Eickhout, B., Bouwman, A.F., van Zeijts, H. (2006), "The role of nitrogen in world food production and environmental sustainability", Agriculture, Ecosystems \& Environment, 116: 4-14, doi: 10.1016/j.agee.2006.03.009. 3.3

Eickhout, B., van Meijl, H., Tabeau, A., van Rheenen, T. (2007), "Economic and ecological consequences of four European land use scenarios", Land Use Policy, 24: 562-575, doi: 10.1016/j.landusepol.2006.01.004. 3.3

Engelen, G., White, R., Ulje, I. (1997), "Integrating constrained cellular automata models, GIS and decision support tools for urban planning and policy making", in Decision Support Systems in Urban Planning, (Ed.) Timmons, H.P.J., pp. 125-155, London (E\&FN Spon). 3.2, 3.2

Fischer, G., van Velthuizen, H.T., Shah, M.M., Nachtergaele, F.O. (2002), "Global Agro-ecological Assessment for Agriculture in the 21st Century: Methodology and Results", RR-02-02, Laxenburg, Austria (International Institute for Applied Systems Analysis (IIASA)). Related online version (cited on 20 March 2008):

http://www.iiasa.ac.at/Research/LUC/SAEZ/index.html. 3.3

Fitz, H.C., DeBellevue, E.B., Costanza, R., Boumans, R., Maxwell, T., Wainger, L., Sklar, F.H. (1996), "Development of a general ecosystem model for a range of scales and ecosystems", Ecological Modelling, 88: 263-295, doi:10.1016/0304-3800(95)00112-3. 3.6

Fohrer, N., Eckhard, K., Haverkamp, S., Frede, H.-G. (2001), "Applying the SWAT Model as a Decision Support Tool for Land Use Concepts in Peripheral Regions in Germany", in Sustaining the Global Farm, (Eds.) Stott, D.E., Mehtar, R.H., Steinhardt, G.C., Selected papers from the 10th International Soil Conservation Organization meeting held May 24-29, 1999, West Lafayette, IN, pp. 994-999, West Lafayette, IN (ISCO/USDA/Purdue University). 3.4

Fohrer, N., Möller, D., Steiner, N. (2002), "An interdisciplinary modelling approach to evaluate the effects of land use systems", Physics and Chemistry of the Earth, 27: 655-662, doi: 10.1016/S1474-7065(02)00050-5. 3.4

Living Reviews in Landscape Research

http://www. livingreviews . org/lrlr-2008-1 
Foley, J.A., DeFries, R., Asner, G.P., Barford, C., Bonan, G., Carpenter, S.R., Chapin, F.S., Coe, M.T., Daily, G.C., Gibbs, H.K., Helkowski, J.H., Holloway, T., Howard, E.A., Kucharik, C.J., Monfreda, C., Patz, J.A., Prentice, I.C., Ramankutty, N., Snyder, P.K. (2005), "Global Consequences of Land Use", Science, 309: 570-574, doi:10.1126/science.1111772. 1

Frede, H.-G., Bach, M., Fohrer, N., Breuer, L. (2002), "Interdisciplinary modeling of the significance of soil functions", Journal of Plant Nutrition and Soil Science, 165: 460-467, doi: 10.1002/1522-2624(200208)165:4¡460::AID-JPLN460;3.0.CO;2-B. 1, 3.4, 3.4

Geist, H.J., Lambin, E.F. (2002), "Proximate causes and underlying driving forces of tropical deforestation", BioScience, 52(2): 143-150, doi:10.1641/00063568(2002)052[0143:PCAUDF]2.0.CO;2. Related online version (cited on 20 March 2008): http://www.geo.ucl.ac.be/LUCC/pdf/02_February_Article_Geist_.pdf. 2, 3.2

GEO (2002), "Global Environment Outlook 3 (GEO-3)", Nairobi, Kenya (UNEP). Related online version (cited on 20 March 2008):

http://www .unep.org/GEO/geo3/. 3.3

GLP (2005), "Science Plan and Implementation Strategy", IHDP Report No. 53 / IHDP Report No. 19, Stockholm (IGBP Secretariat). URL (cited on 20 March 2008):

http://www.igbp.kva.se/documents/resources/report-53.pdf. 1, 2, 1, 2

Gottschalk, T.K., Diekötter, T., Ekschmitt, K., Weinmann, B., Kuhlmann, F., Purtauf, T., Dauber, J., Wolters, V. (2007), "Impact of agricultural subsidies on biodiversity at the landscape level", Landscape Ecology, 22: 643-656, doi:10.1007/s10980-006-9060-8. 3.4, 3.4

Gregersen, J.B., Gijsbers, P.J.A., , Westen, S.J.P. (2007), "OpenMI: Open Modelling Interface", Journal of Hydroinformatics, 9(3): 175-191, doi:10.2166/hydro.2007.023. 5

Grimm, N.B., Faeth, S.H., Golubiewski, N.E., Redman, C.L., Wu, J., Bai, X., Briggs, J.M. (2008), "Global Change and the Ecology of Cities", Science, 319: 756-760, doi:10.1126/science.1150195. 5

Heistermann, M. (2006), "Modelling the Global Dynamics of Rain-fed and Irrigated Croplands. Thesis", Reports on Earth System Science, Hamburg (Planck-Institute for Meteorology). URL (cited on 20 March 2008):

http://www.mpimet.mpg.de/fileadmin/publikationen/Reports/WEB_BzE_37.pdf. 3.5, 3.5

Heistermann, M., Müller, C., Ronneberger, K. (2006), "Land in Sight? Achievements, deficits and potentials of continental to global scale land use modeling", Agriculture, Ecosystems 83 Environment, 114(2-4): 141-158, doi:10.1016/j.agee.2005.11.015. 1

Hoogwijk, M.M., Faaij, A.P.C., Eickhout, B., de Vries, B., Turkenburg, W. (2005), "Potential of biomass energy out to 2100, for four IPCC SRES land-use scenarios", Biomass \&3 Bioenergy, 29: 225-227. 3.3

IPCC (1997), "Revised 1996 IPCC Guidelines for National Greenhouse Gas Inventories, Vol. 2: Workbook", Houghton, J.T., Meira Filho, L.G., Lim, B., Treanton, K., Mamaty, I., Bonduki, Y., Griggs, D.J., Callender, B.A. (Eds.), Bracknell (IPCC/OECD/IEA; UK Meteorological Office). Related online version (cited on 20 March 2008): http://www.ipcc-nggip.iges.or.jp/public/gl/invs5.htm. 3.1

Klein, A.-M., Steffan-Dewenter, I., Tscharntke, T. (2003), "Fruit set of highland coffee increases with the diversity of pollinating bees", Proceedings of the Royal Society of London, Series B: 
Biological Sciences, 270: 955-961, doi:10.1098/rspb.2002.2306. Related online version (cited on 20 March 2008):

http://www.gwdg.de/ uaoe/pdf/paper/ProcRoyalSoc2003, 270_955-961.pdf. 3.7, 3.7

Kuhlmann, F., Möller, D., Weinmann, B. (2002), "Modellierung der Landnutzung: Regionshöfe oder Rasterlandschaft?", Berichte über Landwirtschaft, 80(3): 351-392. 3.4, 3.4

Lambin, E.F., Geist, H. (Eds.) (2006), Land-Use and Land-Cover Change: Local Processes, Global Impacts, Global Change - The IGBP Series, Berlin (Springer). 1

Lambin, E.F., Rounsevell, M.D.A., Geist, H.J. (2000), "Are agricultural land-use models able to predict changes in land-use intensity?", Agriculture, Ecosystems \& Environment, 82(1-3): 321-331, doi:10.1016/S0167-8809(00)00235-8. 1, 4.3

Leemans, R., Eickhout, B. (2004), "Another reason for concern: regional and global impacts on ecosystems for different levels of climate change", Global Environmental Change, 14(3): 219-228, doi:10.1016/j.gloenvcha.2004.04.009. 3.3

Manson, S.M. (2005), "Agent-based modelling and genetic programming for modelling land change in the Southern Yucatán Peninsular Region of Mexico", Agriculture, Ecosystems 85 Environment, 111: 47-62, doi:10.1016/j.agee.2005.04.024. Related online version (cited on 20 March 2008): http://earth.clarku.edu/lcluc/pubs/Modeling/II-10_Manson_2005_.pdf. 3.8, 3.8

Manson, S.M. (2006), "Land use in the southern Yucatán peninsular region of Mexico: Scenarios of population and institutional change", Computers, Environment and Urban Systems, 30: 230253, doi:10.1016/j.compenvurbsys.2005.01.009. 1, 3.8, 3.8

Mather, M. (2006), "Land-Use System", in Our Earth's Changing Land: An Encyclopedia of LandUse and Land-Cover Change, Vol. 2, (Eds.) Geist, H., Lambin, E.F., pp. 379-386, Westport (Greenwood). 2

Mimler, M., Priess, J.A. (2008), "Automated rule set calibration for a regional land use change model", Environmental Modelling \& Software, submitted. 3.7

MNP (2006), "Integrated modelling of global environmental change? An overview of IMAGE 2.4", Bouwman, A.F., Kram, T., Klein Goldewijk, K. (Eds.), Bilthoven (Netherlands Environmental Assessment Agency (MNP)). Related online version (cited on 20 March 2008): http://www.mnp.nl/bibliotheek/rapporten/500110002.pdf. 1, 3.3, 3.3

MODULUS (2000), "MODULUS: A Spatial Modelling Tool for Integrated Environmental DecisionMaking. Final Report, 2 vols.", Engelen, G., van der Meulen, M., Hahn, B., Uljee, I. (Eds.), Maastricht (RIKS). URL (cited on 20 March 2008):

http://www.riks.nl/projects/modulus. Contract ENV4-CT97-0685. Submitted to the Commission of the European Union, Directorate General XII, Environment (IV) Framework, Climatology and Natural Hazards Programme, Brussels, Belgium. 1, 3.2

Möller, D., Weinmann, B., Kirschner, M., , Kuhlmann, F. (1999), "Auswirkungen von Politik- und Strukturmaßnahmen auf räumliche Verteilung und Erfolgskennzahlen der Landnutzung: GISbasierte Simulation mit ProLand", Zeitschrift für Kulturtechnik und Landentwicklung, 40(5/6): 197-201. In German ["Effects of Political and Structural Changes on the Spatial Distribution and Key Indicators of Land Use: GIS based Simulation with ProLand"]. 3.4

Müller, C., Eickhout, B., Zaehle, S., Bondeau, A., Cramer, W., Lucht, W. (2007), "Effects of changes in $\mathrm{CO}_{2}$, climate, and land use on the carbon balance of the land biosphere during the 21st century", Journal of Geophysical Research, 112, G02032, doi:10.1029/2006JG000388. 3.3

Living Reviews in Landscape Research

http://www. livingreviews . org/lrlr-2008-1 
Nellemann, C., Kullerud, L., Vistnes, I., Forbes, B.C., Husby, E., Kofinas, G.P., Kaltenborn, B.P., Rouaud, J., Magomedova, M., Bobiwash, R., Lambrechts, C., Schei, P.J., Tveitdal, S., Grøn, O., Larsen, T.S. (UNEP) (2001), "GLOBIO: Global methodology for mapping human impacts on the biosphere", Environment Information and Assessment Technical Reports, UNEP/DEWA/TR.01-3, Nairobi, Kenya (United Nations Environment Programme). Related online version (cited on 20 March 2008):

http://www.globio.info/region/polar/. 3.3

Overmars, K.P., Verburg, P.H., Veldkamp, A. (2007), "Comparison of a deductive and an inductive approach to specify land suitability in a spatial explicit land use model", Land Use Policy, 24 (3): 584-599, doi:10.1016/j.landusepol.2005.09.008. 3.1

Oxley, T., McIntosh, B.S., Winder, N., Mulligan, M., Engelen, G. (2004), "Integrated modelling and decision-support tools: a Mediterranean example", Environmental Modelling $\mathscr{B}$ Software, 19(11): 999-1010, doi:10.1016/j.envsoft.2003.11.003. Related online version (cited on 20 March 2008):

http://www.tigress.ac/oxley/EMS_19(11)pp999-1010.pdf. 3.2

Parker, D.C., Manson, S.M., Janssen, M.A., Hoffmann, M.J., Deadman, P. (2002), "Multi-Agent Systems for the Simulation of Land-Use and Land-Cover Change: A Review", Annals of the Association of American Geographers, 93(2): 314-337, doi:10.1111/1467-8306.9302004. Related online version (cited on 20 March 2008):

http://www.csiss.org/events/other/agent-based/papers/maslucc_overview.pdf. 1, 3.8

Parton, W.J., Harmann, M., Ojima, D.S., Schimel, D. (1998), "DAYCENT and its land surface submodel: description and testing", Global and Planetary Change, 19: 35-48, doi:10.1016/S09218181(98)00040-X. 3.5, 3.7, 3.7

Pontius Jr, R.G., Cornell, J.D., Hall, C.A.S. (2001), "Modeling the spatial pattern of land-use change with GEOMOD2: application and validation for Costa Rica", Agriculture, Ecosystems Ef Environment, 85(1-3): 191-203, doi:10.1016/S0167-8809(01)00183-9. 1

Priess, J.A., de Koning, G.H.J., Veldkamp, A. (2001), "Assessment of interactions between land use change and carbon and nutrient fluxes in Ecuador", Agriculture, Ecosystems $\& 3$ Environment, 85: 269-279, doi:10.1016/S0167-8809(01)00193-1. 3.1, 3.1

Priess, J.A., Mimler, M., Klein, A.-M., Schwarze, S., Tscharntke, T., Steffan-Dewenter, I. (2007a), "Linking deforestation scenarios to pollination services and economic returns in coffee agroforestry systems", Ecological Applications, 17: 407-417, doi:10.1890/05-1795. 1, 3.7

Priess, J.A., Mimler, M., Weber, R., Faust, H. (2007b), "Socio-Environmental Impacts of Land Use and Land Cover Change at a Tropical Forest Frontier", in MODSIM 2007, (Eds.) Oxley, L., Kulasiri, D., International Congress on Modelling and Simulation, 10-13 December 2007, Christchurch, New Zealand, pp. 349-357, Canberra (Modelling and Simulation Society of Australia and New Zealand). Related online version (cited on 20 March 2008):

http://mssanz.org.au/MODSIM07/papers/5_s45/Socio-environmental_s45_Priess_.pdf. $1,3.7$

Reiher, W., Breuer, L., Weinmann, B., Pohlert, T., Bach, M., Düring, R.-A., Gäth, S., Frede, H.-G. (2006), "The integrated model network ITE ${ }^{2} \mathrm{M}$ : model set-up and assessment of agricultural land use and management options", in Proceedings of the iEMSs Third Biennial Meeting 'Summit on Environmental Modelling and Software', (Eds.) Voinov, A., Jakeman, A.J., Rizzoli, A.E., Burlington, USA, July 9-13, 2006, Manno (International Environmental Modelling and Software 
Society). URL (cited on 20 March 2008):

http://www.iemss.org/iemss2006/sessions/all.html. 3.4, 3.4

Rockström, J., Gordon, L., Folke, C., Falkenmark, M., Engwall, M. (1999), "Linkages Among Water Vapour Flows, Food Production and Terrestrial Ecosystem Services", Conservation Ecology, 3(2), 5. URL (cited on 20 March 2008):

http://www.consecol.org/vol3/iss2/art5/. 1

Rosegrant, M.W., Cai, X., Cline, S.A. (2002), "World Water and Food to 2025: Dealing with Scarcity", Washington, DC (International Food Policy Research Institute). URL (cited on 20 March 2008):

http://www.ifpri.org/pubs/books/oc42.asp. 3.5

Rossing, W.A.H., Zander, P., Josien, E., Groot, J.C.J., Meyer, B.C., Knierim, A. (2007), "Integrative modelling approaches for analysis of impact of multifunctional agriculture: A review for France, Germany and The Netherlands", Agriculture, Ecosystems E Environment, 120: 41-57, doi:10.1016/j.agee.2006.05.031. 1

Sala, O.E., Chapin III, F.S., Armesto, J.J., Berlow, E., Bloomfield, J., Dirzo, R., Huber-Sanwald, E., Huenneke, L.F., Jackson, R.B., Kinzig, A., Leemans, R., Lodge, D.M., Mooney, H.A., Oesterheld, M., Poff, N.L., Sykes, M.T., Walker, B.H., Walker, M., Wall, D.H. (2000), "Global biodiversity scenarios for the year 2100", Science, 287: 1770-1774, doi:10.1126/science.287.5459.1770. 1

Scenarios Working Group (2005), "Ecosystems and Human Well-being: Scenarios", Carpenter, S.R., Pingali, P.L., Bennett, E.M., Zurek, M.B. (Eds.), Millennium Ecosystem Assessment Series, 2, Washington, DC et al. (Island Press). Related online version (cited on 20 March 2008): http://www.millenniumassessment.org/en/Scenarios.aspx. 3.3

Schaldach, R., Alcamo, J., Heistermann, M. (2006), "The multiple-scale land use change model LandShift: A scenario analysis of land use change and environmental consequences in Africa.", in Proceedings of the iEMSs Third Biennial Meeting 'Summit on Environmental Modelling and Software', (Eds.) Voinov, A., Jakeman, A.J., Rizzoli, A.E., Burlington, USA, July 9-13, 2006, Manno (International Environmental Modelling and Software Society). URL (cited on 20 March 2008):

http://www.iemss.org/iemss2006/sessions/all.html. 1, 3.5

Schaldach, R., Priess, J.A., Alcamo, J. (2008), "Simulating the impact of bio-fuel development on country-wide land-use change in India", Biomass $\&$ Bioenergy, submitted. 3.5

Schoorl, J.M., Boix Fayos, C., de Meijer, R.J., van der Graaf, E.R., Veldkamp, A. (2004), "The ${ }^{137}$ Cs technique applied to steep Mediterranean slopes (Part II) landscape evolution and model calibration", Catena, 57(1): 35-54, doi:10.1016/j.catena.2003.08.002. 3.1

Sitch, S., Smith, B., Prentice, I.C., Arneth, A., Bondeau, A., Cramer, W., Kaplan, J.O., Levis, S., Lucht, W., Sykes, M.T., Thonicke, K., Venevsky, S. (2003), "Evaluation of ecosystem dynamics, plant geography and terrestrial carbon cycling in the LPJ dynamic global vegetation model", Global Change Biology, 9(2): 161-185, doi:10.1046/j.1365-2486.2003.00569.x. 3.3

Smaling, E.M.A., Fresco, L.O. (1993), "A decision-support model for monitoring nutrient balances under agricultural land use (NUTMON)", Geoderma, 60: 235-256, doi:10.1016/00167061(93)90029-K. 3.1 
Stehfest, E., Heistermann, M., Priess, J.A., Ojima, D.S., Alcamo, J. (2007), "Simulation of global crop production with the Ecosystem Model DayCent", Ecological Modelling, 209(2-4): 203-219, doi:10.1016/j.ecolmodel.2007.06.028. 3.5, 3.7

Strengers, B., Leemans, R., Eickhout, B., de Vries, B.J.M., Bouwman, A.F. (2004), "The land-use projections in the IPCC SRES scenarios as simulated by the IMAGE 2.2 model", GeoJournal, 61: 381-393, doi:10.1007/s10708-004-5054-8. 3.3

Turner II, B.L., Cortina Villar, S., Foster, D., Geoghegan, J., Keys, E., Klepeis, P., Lawrence, D., Macario Mendoza, P., Manson, S.M., Ogneva-Himmelberger, Y., Plotkin, A.B., Pérez Salicrup, D., Chowdhury, R.R., Savitsky, B., Schneider, L., Schmook, B., Vance, C. (2001), "Deforestation in the southern Yucátan peninsular region: an integrative approach", Forest Ecology and Management, 5521: 1-18, doi:10.1016/S0378-1127(01)00508-4. 3.8

van Delden, H., Luja, P., Engelen, G. (2007), "Integration of multi-scale dynamic spatial models of socio-economic and physical processes for river basin management", Environmental Modelling ES Software, 22: 223-238, doi:10.1016/j.envsoft.2005.07.019. Related online version (cited on 20 March 2008):

http://www.iemss.org/iemss2004/pdf/integratedmodelling/van\%20inte.pdf. 3.2, 3.2

van Meijl, H., van Rheenen, T., Tabeau, A., Eickhout, B. (2007), "The impact of different policy environments on agricultural land use in Europe", Agriculture, Ecosystems \& Environment, 114: 21-38, doi:10.1016/j.agee.2005.11.006. 3.3

van Tongeren, F., van Meijl, H., Surry, Y. (2001), "Global models applied to agricultural and trade policies: a review and assessment", Agricultural Economics, 26(2): 149-172, doi:10.1016/S01695150(00)00109-2. 1

Veldkamp, A., Fresco, L.O. (1996), "CLUE-CR: An integrated multi-scale model to simulate land use change scenarios in Costa Rica", Ecological Modelling, 91(1-3): 231-248, doi:10.1016/03043800(95)00158-1. 1

Veldkamp, A., Verburg, P.H., Kok, K., de Koning, G.H.J., Priess, J.A., Bergsma, A.R. (2001), "The need for scale sensitive approaches in spatially explicit land use change modeling", Environmental Modeling \& Assessment, 6: 111-121, doi:10.1023/A:1011572301150. 1, 3.1

Verburg, P.H. (2006), "Simulating feedbacks in land use and land cover change models", Landscape Ecology, 21: 1171-1183, doi:10.1007/s10980-006-0029-4. 3.1, 3.1, 4.3

Verburg, P.H., Denier van der Goon, A.C. (2001), "Spatial and temporal dynamics of methane emissions from agricultural sources in China", Global Change Biology, 7: 31-47, doi:10.1046/j.13652486.2001.00389.x. 3.1, 3.1, 4.4

Verburg, P.H., de Koning, G.H.J., Kok, K., Veldkamp, A., Bouma, J. (1999a), "A spatial explicit allocation procedure for modelling the pattern of land use change based upon actual land use", Ecological Modelling, 116(1): 45-61, doi:10.1016/S0304-3800(98)00156-2. 3.1

Verburg, P.H., Veldkamp, A., Bouma, J. (1999b), "Land use change under conditions of high population pressure:the case of Java", Global Environmental Change, 9: 303-312, doi:10.1016/S09593780(99)00175-2. 3.1

Verburg, P.H., Veldkamp, A., Fresco, L.O. (1999c), "Simulation of changes in the spatial pattern of land use in China", Applied Geography, 19(3): 211-233, doi:10.1016/S0143-6228(99)00003-X. 3.1 
Verburg, P.H., Soepboer, W., Veldkamp, A., Limpiada, R., Espaldon, V., Mastura, S.S.A. (2002), "Modeling the Spatial Dynamics of Regional Land Use: The CLUE-S Model", Environmental Management, 30(3): 391-405, doi:10.1007/s00267-002-2630-x. 3.1, 3.1

Verburg, P.H., Schota, P., Dijsta, M., Veldkamp, A. (2004), "Land use change modelling: current practice and research priorities", GeoJournal, 61: 309-324. 1

Verburg, P.H., Kok, K., Pontius, R.G., Veldkamp, A. (2006a), "Modelling Land-use and Landcover change", in Land-Use and Land-Cover Change: Local Processes, Global Impacts, (Eds.) Lambin, E.F., Geist, H., Global Change - The IGBP Series, Berlin (Springer). 1, 4.1

Verburg, P.H., Schulp, C.J.E., Witte, N., Veldkamp, A. (2006b), "Downscaling of land use change scenarios to assess the dynamics of European landscapes", Agriculture, Ecosystems 63 Environment, 114: 39-56, doi:10.1016/j.agee.2005.11.024. 3.1

Voinov, A.A., Costanza, R., Wainger, L., Boumans, R.M.J., Villa, F., Maxwell, T., Voinov, H. (1999a), "Patuxent landscape model: integrated ecological economic modelling of a watershed", Environmental Modelling ES Software, 14: 473-491, doi:10.1016/S1364-8152(98)00092-9. 3.6, 3.6

Voinov, A.A., Voinov, H., Costanza, R. (1999b), "Surface water flow in landscape models: 2. Patuxent watershed case study", Ecological Modelling, 119: 211-230, doi:10.1016/S03043800(99)00056-3. 3.6

Wassenaar, T., Gerber, P., Rosales, M., Ibrahim, M., Verburg, P.H., Steinfeld, H. (2007), "Projecting land use changes in the Neotropics: The geography of pasture expansion into forest", Global Environmental Change, 17: 86-104, doi:10.1016/j.gloenvcha.2006.03.007. 3.1

White, R., Engelen, G. (1997), "Cellular Automata as the Basis of Integrated Dynamic Regional Modelling", Environment and Planning B: Planning and Design, 24: 235-246, doi: 10.1068/b240235. 3.2, 3.2

Williams, J.R., Jones, C.A., Dyke, P.T. (1990), "The EPIC model documentation", Washington, D.C. (U.S. Department of Agriculture). 3.4 